Amasya Ilahiyat Dergisi - Amasya Theology Journal

ISSN 2667-7326 | e-ISSN 2667-6710

Haziran / June 2020, 14: 259-291

\title{
Geçmişten Günümüze Dini Gruplar Olarak Tarikatların Siyasi Yapılarla İlişkileri
}

\section{The Relationship Between the Sect as Religious Group and Political Structures from Past to Nowadays}

\author{
Abdulhamit BUDAK \\ Dr. Öğr. Üyesi, Amasya Üniversitesi, İlahiyat Fakültesi, \\ Din Bilimleri Anabilim Dalı \\ Assistant Professor, Amasya University, Faculty of Theology, \\ Department of Science of Religion \\ Amasya, Turkey \\ abudak1@hotmail.com \\ orcid.org/0000-0003-4253-2315
}

\section{Makale Bilgisi / Article Information}

Makale Türü / Article Types: Araştırma Makalesi / Research Article

Geliş Tarihi / Received: 17 Ağustos / August 2018

Kabul Tarihi / Accepted: 28 Ekim / October 2018

Yayın Tarihi / Published: 30 Haziran / June 2020

Yayın Sezonu / Pub. Date Season: Haziran / June

Sayı / Issue: 14 Sayfa / Pages: 259-291

Atıf / Cite as: Budak, Abdulhamit. "Geçmişten Günümüze Dini Gruplar Olarak Tarikatların Siyasi Yapılarla İlişkileri [The Relationsship Between the Sect as Religious Group and Political Structures From Past to Nowadays]". Amasya Ilahiyat Dergisi-Amasya Theology Journal 14 (June 2020): 259-291.

https://doi.org/10.18498/amailad.581691.

Intihal / Plagiarism: Bu makale, en az iki hakem tarafından incelendi ve intihal içermediği teyit edildi. / This article has been reviewed by at least two referees and scanned via a plagiarism software.

Copyright (C) Published by Amasya Üniversitesi, İlahiyat Fakültesi / Amasya University, Faculty of Theology, Amasya, 05100 Turkey. All rights reserved. https://dergipark.org.tr/amailad. 
260 | A. BUDAK / Geçmişten Günümüze Dini Gruplar Olarak Tarikatların Siyasi Yapılarla İlişkileri

\section{The Relationship Between the Sect as Religious Group and Political Structures from Past to Nowadays}

\section{Abstract}

Religious groups are social structures that is consisted of by people sharing the same beliefs. While performing their own rituals, they have interacted with other institutions as a result of necessity to live in a social world. Specially, the relations with the political institution and the results of these relations are being extensively discussed by the public opinion today. The point that we have recently experienced has shown us how crucial the problem is. The events of nowadays are not social events that did not take place within the history but the same events each event has its historical pass and background. So, the political relationship observed between religious groups today is very reflection of done and experiences that have occurred over hundreds of years.

Knowing the principle 'today cannot be interpreted without understanding past', analyzing and examining the relations of the sects of the major religious groups in our history with the political structure will help us to analyze and understand the events that has taken place recently. For this purpose in this article, we will examine the interrelationship of Khalwati Tradition an important religious sects in social structure of Ottoman empire with other political groups and political role it played. By understanding this structure. We will reveal what political groups expect from religious groups and relationships of religious groups with political structure by holding projection from past to today.

\section{Summary}

The relationship between religious groups and political structures is one of the important issues in the field of social sciences, and both today's and history's relations are approached with interest by scientists. The reason for this interest is the emergence of the effects of interactions between religious groups and political structures affecting large communities and creating significant changes in political structures.

The fact that Mystic religious groups, who are considered to accept a far-off, ascetic lifestyle as their philosophy of life, have problems that require the analysis of the questions of which social reasons they are in such a relationship, or from which rational needs of rulers who hold the elements of worldly power, are the main reasons that intensify the research in this field

Examining interaction between the religious group observed in the backgrounds of societies and political structures helps to determine the 
characteristic behaviors of existing groups that are not independent of the past, and also helps to understand the actions they develop and will develop. In this sense, examining such interactions that occur in the history of societies, revealing the relationship between cause and effect, helps to analyze the functioning of religious groups, which are an element of social structure, and to understand the preferences of political structures in decision making.

The undeniable authority of the charismatic leaders of religious groups over the masses and the organizational formation of religious groups reinforced by spiritual motivations have always caused hesitation and fear in those who maintain the political structure. This concern resulted in the political authority developing two types of measures against the religious group: firstly; abolish the authority by declaring the religious group as an illegitimate structure or use the military force it holds to reduce its influence. Secondly; to think that the military power will cause greater reactions, to recognize the religious group politically and to take control of it by keeping it within the system, and to make use of it in order to continue its existence.

The public power and the interests gained by the political structure have always attracted the attention of other structures of the society, and the ability to capture the opportunities to benefit from it has strengthened the social structures and provided them with advantages over their competitor. As such, social structures have been in competition with other similar structures in order to maintain what they have achieved and to move themselves to an even more advantageous position.

Although religious groups have inculcated the opposite to their affiliates within their structures, they have not been able to ignore the advantages of being side by side with representatives of political structures and have even been jealous of the political connections of other religious groups. This was perhaps a consensual relationship in order to make the group led by the religious leader more institutional and to eliminate the negative actions of its competitors, perhaps as a result of the different expectations of the group's affiliates, which compelled the leader to accept, beyond these, the natural and human expectations of the leader could be a result.

The relationship of the Ottoman state structure with religious groups, which has a strict and uncompromising form of decentralized administration and which has an overreactive behavior regarding actions and thoughts that would harm the central government, has an aspect worth examining. The prospect of the emergence of small or large alternative powers in a country ruled by a 
262 | A. BUDAK / Geçmişten Günümüze Dini Gruplar Olarak Tarikatların Siyasi Yapılarla İlişkileri charismatic and absolute-authority Sultan has been an issue to follow and has always unsettled the rulers. As a result of this unease, religious groups and their influence on the masses, which have the power to make the political power of the administration debatable, have led to the close follow-up of unquestionable charismatic leaders and, when necessary, to be called to the center and questioned.

The above findings on the relations between religious groups and political structures are not only the facts observed in history, but also the events we are watching, living and observing today. The process that Turkey went through on July 15th shows how important it is to understand the sociology of religious groups and to analyze their relations with the political structure. Social sciences, especially in the field of Sociology of religion related to this subject by using their own scientific methods to analyze, a reality of the Society of politics and religious institutions in the past and today should be able to reveal the relationships. This will help minimize the conflicts observed between religious groups and the political structure, but also minimize the social tension in society.

In this article, we will discuss the relations of religious groups with political structures within the framework of the facts we have revealed above. As an example, the relations of the Halveti sect, which emerged as an active religious group in the fifteenth century, with the political structure of that period will be examined and discussed and the above-mentioned thoughts on the relations of the political structure of the religious group will be discussed.

Keywords: Sociology of Religion, Religious Groups, Halveti Order, Politics, Bayezid.

\section{Geçmişten Günümüze Dini Gruplar Olarak Tarikatların Siyasi Yapılarla İlişkileri}

Öz

Dini gruplar, ortak inanç esasları etrafında toplanan bireylerin meydana getirdiği sosyal yapılardır. Bu yapılar kendi iç aktivitelerini yerine getirirken toplumsal bir dünyada yaşamanın gereği olarak diğer kurumlarla da etkileşim içerisinde olagelmişlerdir. Özellikle siyaset kurumuyla olan ilişkileri ve bu ilişkilerin sonuçları günümüzde kamuoyu tarafından yoğun olarak tartışılmaktadır. Son dönemlerde yaşadığımız olayların toplumu getirdiği nokta problemin ne kadar önemli olduğunu ortaya koymaktadır. Bugün yaşanan olaylar tarihten kopuk sosyal hadiseler olmayıp her bir olayın tarihsel geçmişi 
ve arka planı vardır. Bu nedenle bugün gözlemlenen dini gruplar siyaset ilişkisi yüzlerce yılda meydana gelen birikim ve tecrübelerin günümüze yansımasıdır. Geçmiş anlaşılmadan bugün yorumlanamaz ilkesinden hareketle tarihimizdeki önemli dini gruplardan olan tarikatların siyasal yapı ile olan ilişkilerini ele alıp incelemek günümüzde meydana gelen olayları çözümlemeye ve anlamaya yardım edecektir. Bu amaçla Osmanlı toplum yapısı içinde önemli bir dini grup olan Halvetî Tarikatı'nın siyasi yapılarla olan ilişkilerini ve oynadığı siyasal rolü bu makalede ele alıp inceleyeceğiz. Bu yapı üzerinden geçmişten günümüze bir projeksiyon tutarak siyasi yapıların dini gruplardan beklentisini, dini grupların da siyasal yapıyla olan ilişkilerini ortaya koyacağız.

Anahtar Kelimeler: Din Sosyolojisi, Dini Gruplar, Halveti Tarikatı, Siyaset, Bayezid.

\section{Giriş}

Dini grupların siyasi yapılarla olan ilişkileri toplum bilimleri sahasının dikkat çeken konularından biri olup gerek günümüzdeki ve gerekse tarih içerisindeki ilişkileri bilim adamları tarafından ilgiyle ele alınıp incelenmektedir. Bu ilginin sebebi dini gruplar ile siyasi yapılar arasındaki etkileşimlerin geniş toplulukları etkileyen sonuçlarının ortaya çıkması ve siyasi yapılarda önemli değişiklikler meydana getirmesidir.

Dünyadan uzak, asketik bir hayat tarzını kendilerine yaşam felsefesi olarak kabul ettiği düşünülen mistik dini grupların hangi toplumsal nedenlerden dolayı böyle bir ilişkinin içerisinde oldukları ya da dünyevi iktidar unsurlarını elinde bulunduran yöneticilerin hangi rasyonel ihtiyaçtan böyle bir ilişki kurdukları sorularının kendi içerisinde çözümlenmesini gerektiren problemler içermesi bu alandaki araştırmaları yoğunlaştıran temel nedenlerdir.

Toplumların geçmişlerinde gözlenen dini grup, siyasal yapı etkileşimlerini incelemek, geçmişten bağımsız olmayan mevcut grupların bu alandaki karakteristik davranışlarını belirlemeye yardım ederken aynı zamanda mevcut siyasi yapılarında geliştirdikleri ve geliştirecekleri eylemleri anlamaya yardımcı olur. $\mathrm{Bu}$ anlamda toplumların tarihinde meydana gelen bu tür etkileşimleri incelemek, sebep ve sonuç ilişkilerini ortaya koymak, toplumsal yapının bir unsuru olan dini grupların işleyişini çözümlemeye ve siyasi yapıların karar 
264 | A. BUDAK / Geçmişten Günümüze Dini Gruplar Olarak Tarikatların Siyasi Yapılarla İlişkileri verme noktasında ne tür tercihler içerisinde bulunduklarını anlamaya yardımci olur.

Dini grupların karizmatik liderlerinin kitleler üzerindeki yadsınamaz otoritesi ve dini grupların manevi motivasyonlarla güçlendirilmiş örgütsel oluşumları siyasal yapıyı devam ettirenlerde her zaman tereddüt ve korku meydana getirmiştir. Bu endişe siyasi otoritenin dini gruba karşı iki tür tedbir geliştirmesi sonucunu doğurmuştur: birincisi; otoritenin dini grubu gayri meşru bir yapılanma olarak ilan ederek ortadan kaldırması veya etkisini azaltmak için elinde bulundurduğu askeri gücü kullanması. İkincisi; askeri gücün daha büyük tepkilere yol açacağını düşünüp dini grubu siyasi açıdan tanımak ve onu sistem içerisinde tutarak kontrol altına almak, daha da ötesinde kendi varlığını devam ettirmek için ondan yararlanmak. ${ }^{1}$

Siyasal yapının elinde bulundurduğu kamu gücü ve onunla elde ettiği çıarlar toplumun diğer yapılarının her zaman dikkatini çekmiş ve ondan istifade edebilme imkânlarını yakalayabilmek toplumsal yapılara güç kazandırmış ve kendi rakipleri nazarında da onlara avantajlar sağlamıştır. Bu haliyle toplumsal yapılar elde ettiklerini korumak ve kendilerini daha da avantajlı bir konuma taşımak için diğer benzer yapılarla rekabet içinde olmuşlardır. ${ }^{2}$

Dini gruplar yapıları içerisindeki bağlılarına tersini telkin etmiş olsalar da siyasi yapı temsilcileriyle yan yana olmanın sağladığı avantajları göz ardı edememişler hatta diğer dini grupların siyasi bağlantılarını kıskanmışlardır. Bu belki dini liderin yönettiği grubun kurumsal açıdan daha güçlü olmasını sağlamak ve rakiplerinin olumsuz eylemlerini bertaraf edebilmek için rıza gösterilen bir ilişki olmuş belki de grubun bağlılarının farklı beklentileri sonucunda lideri mecbur kılan bir kabulleniş olmuş, bunlarında ötesinde liderin doğal, insani beklentilerinin bir sonucu da olabilmiştir. ${ }^{3}$

Sıkı ve tavizsiz merkeziyetçi yönetim biçimine sahip olan ve merkezi yönetime zarar verecek eylemler ve düşünceler konusunda aşırı tepkisel bir davranış gösteren Osmanlı devlet yapısının dini gruplarla olan ilişkisi incelenmeye değer bir yön içermektedir. ${ }^{4}$ Karizmatik ve

1 Şerif Mardin, Din ve İdeoloji (İstanbul: İletişim Yayınları, 1992), 95-95.

2 Sabri Ülgener, Zihniyet ve Din (İstanbul: Derin Yayınları, 2006), 136.

3 Max Weber, Din Sosyolojisi, çev. Latif Boyacı (İstanbul: Yarın Yayınları, 2012), 365367.

4 D. Mehmet Doğan, Tarih ve Toplum (Ankara: Rehber Yayınları, 1989), 101-102. 
mutlak otorite sahibi bir sultanın yönettiği ülkede küçük veya büyük alternatif güçlerin ortaya çıkma ihtimali, takip edilmesi gereken bir konu olmuş ve yöneticileri her zaman tedirgin etmiştir. Bu tedirginliğin sonucu olarak da yönetimin siyasi gücünü tartışılır hale getirme gücüne sahip olan dini gruplar ve onların kitleler üzerinde etkisi, tartışılmaz karizmatik liderlerin yakından takip edilmesine, gerektiğinde de merkeze çağırılarak sorguya tabi tutulmasına sebebiyet vermiştir. ${ }^{5}$

Dini gruplar ile siyasi yapılar arasındaki ilişkiler konusunda yukarıda ortaya koyduğumuz tespitler sadece tarih içerisinde gözlenen olgular olmayıp bugün de yakinen izlediğimiz, yaşadığımız, gözlemlediğimiz olaylardır. 15 Temmuz'da Türkiye'nin içerisinden geçtiği süreç dini grupların sosyolojisini anlamanın ve onların siyasi yapıyla olan ilişkilerinin tahlil edilmesinin ne kadar önemli olduğunu göstermektedir. Toplum bilimleri özelikle Din Sosyolojisi alanına giren bu konuyla alakalı kendi bilimsel metotlarını kullanarak çözümlemeler yapmalı, toplumun bir realitesi olan siyaset ve din kurumlarının geçmişteki ve bugün ki ilişkilerini ortaya koyabilmelidir. Bu durum dini gruplar ile siyasi yapı arasında gözlemlenen çatışmaların asgariye indirilmesine yardımcı olmakla beraber toplumda meydana getirdiği sosyal gerginliği de minimize edecektir.

$\mathrm{Bu}$ makalede dini grupların siyasi yapılarla olan ilişkilerini yukarıda ortaya koyduğumuz olgular çerçevesinde ele alacağız. Örneklem olarak on beşinci yüzyılda etkin bir dini grup olarak ortaya çıkan Halveti Tarikatı'nın o dönemki siyasi yapıyla olan ilişkileri ele alınıp incelenecek ve dini grup siyasi yapı ilişkileri ile ilgili yukarıda ortaya konulan düşünceler tartışılacaktır.

\section{Dini Grup Olarak Tarikat}

Bireylerin birbirleriyle ilişki kurmak suretiyle sosyal örüntü meydana getirdikleri toplumsal yapilar olarak tanimlanan gruplar, insanların her yerde ve her zamanda aile, eğitim, ekonomi, siyaset, din etkinliklerinde sosyal ihtiyaçlarını karşılamak gibi fonksiyonları üstlenirler. Gruplar; aile grupları, eğitim grupları, ekonomi grupları, siyasal gruplar, dini gruplar gibi sinıflandirmalara tabi tutulurlar. ${ }^{6}$

5 Ünver Günay - A. Vehbi Ecer, Tasavvuf, Tarikatlar ve Türkiye (Kayseri: Erciyes Üniversitesi Yayınları, 1999), 193.

6 Joseph Ficther, Sosyoloji Nedir?, çev. Nilgün Çelebi (Ankara: Attila Kitabevi, 1996), 5258. 
Dini gruplar; inanç ve ibadet alanlarında benzer dini değerleri paylaşan ve ortak dini davranış sergileyen kişilerin meydana getirdiğ $i$ örüntülerden doğan gruplardır. Tanrı ve insan arasındaki ilişkiler bu grupların öne çıkan özelliğidir. Dini gruplar; doğal dini gruplar, salt dini gruplar olmak üzere iki gruba ayrılırlar. Doğal dini gruplar; aile, klan, boy ve kabile gibi genellikle soy bağı ile birbirine bağlanmış üyelerin dini birlikteliğini oluşturan gruplardır. Salt dini gruplar; sadece dini ilgiler çerçevesinde meydana gelen, belli bir dinin iman, ibadet ve ahlaki esaslarını tek ölçüt olarak kabul eden toplumsal grup yapılarıdır. ${ }^{7}$

Salt dini gruplarda üyelerin birbiriyle olan ilişkileri din kardeşliği esasına dayandığı için manevi ve dini bağ, kan ve akrabalık bağından daha güçlü olup grup manevi bir bütünlük arz eder. Bu duygu onu akrabalık bağlarının da önüne geçirir. Salt dini gruplar kendi içlerinde farklı siniflandirmalara tabi tutulurlar. Bunlar; ilkel ve milli dinler çerçevesinde dini gruplar, evrensel dinler çerçevesinde dini gruplar, ihvan birlikleri, itizali gruplar ve mezhepler, tarikatlar olarak siralanabilir. ${ }^{8}$

Sosyoloji ilmi açısından tarikatlar ana dini gruba yapılan itirazların sonucu ortaya çıkmış toplumsal gruplardır. Tüm evrensel dinlerde görülen bu gruplar ana dini yapıdaki bazı gelişmelere muhalif olarak, dini daha sıkı ve yoğun yaşama talebinin sonucu ortaya çıkmıştır. Dini olarak ortak bir takva hayatına yönelenler tarafından oluşturulan tarikatlar, üyelerinden sadece kendilerine mensup olmalarını isteme, sürekli sadakat duygusu, özel kıyafet giyme, özel ritüeller, aynı yerde ikamet, beraber yemek yeme gibi özelliklere sahip olmalarını isterken, diğer tarikatlarla olan ilişkilerinde, kendilerinin farklı ve üstün olma yönlerini ortaya çıkarmak suretiyle etnosantrik özellikler de taşımaktadırlar. ${ }^{9}$

Tasavvuf düşüncesi açısından tarikat şu şekillerde tanımlanmaktadır; "Allah'ın hoşnutluğunu elde etmek ve onu görüyormuş gibi ibadet yapma bilincini kazanmak için girilen ve kendisine ait kuralları olan yol, Kur'an-1 Kerim ve Hz. Muhammed'in sünnetinde emredilen şeyleri ilahi aşkın etkisiyle coşkulu bir şekilde yaşam yolu veya kişinin İslam'ın emir ve yasaklarına göre hareket eden,

\footnotetext{
Necdet Subaşı, Din Sosyolojisi (İstanbul: Dem Yayınları, 2014), 113-114.

Ünver Günay, Din Sosyolojisi (İstanbul: İnsan Yayınları, 2000), 252-285.

9 Niyazi Akyüz, Dinin Örgütsel İklimi (Ankara: Gündüz Yayıncılık, 2007), 117-118.
} 
kâmil bir mürşidin önderliğinde, Allah'ın hoşnutluğunu kazanmak ve Hz. Muhammed'in örnek ahlakıyla ahlaklanmak amacıyla yapmış olduğu manevi yolculuk; bu uğurda takip ettiği yol, metot."10

Tarikat; zevk, neşe, irfan, aşk ve cezbe yolu olup kulu Allah'a ulaştırır. Bu yolu seçen mürid, sûfîlere göre, varlı̆̆ını Rabbine teslim eder; bütün mahlukatta onun kudret ve hikmetini görür; tuttuğu yola göre kendi fânî varlığını ve bütün fâni varlıkları, gerçek var olan Alllah'da yok eder; onun varlığıyla var olduğunu bilir; bilişi, görüş, görüşü de oluş haline gelir. ${ }^{11}$

\section{Halveti Tarikatı}

Halvetî Tarikatı'nın kurucusu olan Ebu Abdillah Siracüddin Ömer b. Şeyh Ekmelüddin el-Gilani el-Halvetî, (ö. 750/1349) aslen Şirvanlı olup İran'ın Gîlan bölgesinde, Hazar denizinin kıyısına yakın bir yerde bulunan Lahican şehrinde dünyaya gelmiştir. ${ }^{12}$

Halvetîyye'nin kurucusu Ömer el-Halvetî olsa da tarikatı geniş coğrafyalar ve kitlelerle tanıştıran Yahya-yı Şirvani olmuştur. Ömer Halvetî döneminde tarikat Şirvan çevresinden çıkamamış, yerel bir tarikat olarak kalmıştır. Tarikatı hak ettiği yere ulaştıran ve tanınmasını sağlayan ve bu nedenle de haklı olarak "Pîrî Sânî" yani "ikinci pîr" lakâbıyla anılan kişi Yahya-yı Şirvanî’dir (ö. 869/1464-65). Yahya eşŞirvani, Halvetî tarikatını yeniden yapılandırıp yaydığı için Halvetîyye' nin kollarının hepsinin başında onun ismi bulunur. ${ }^{13}$

Yahya Sirvânî'nin halifelerinin Anadolu'da irşad faaliyetine başlamalarından önce Niğde ve Sivas gibi, Amasya'nın da Halvetîler için uygun bir mekân olduğu görülmektedir. Halvetîliği Amasya'ya getiren ve bu şehrin âdeta bir Halvetî merkezi olmasına sebep olan kişi, Pîr İlyas el-Amâsî'dir (ö. 837/1433-34). Sadreddin Hryavi'nin halifelerinden olan Pir İlyas, Amasyalı meşhur bir âlimdir. ${ }^{14}$

10 Heyet, “Tarikat”, Dini Terimler Sözlü̆g̈ü (Ankara: Milli Eğitim Bakanlığı Devlet Kitapları Müdürlüğ̈̈, 2009), 350-351.

11 Abdülbâki Gölpınarlı, Yüz Soruda Türkiye'de Mezhepler ve Tarikatlar (İstanbul: Gerçek Yayinevi, 1969), 186.

12 Enver Behnan Şapolyo, Mezhepler ve Tarikatlar Tarihi (İstanbul: Milenyum Yayınları, 2013), 200-203.

13 Mehmet Serhan Tayşi, “Ömer Halvetî”, Türkiye Diyanet Vakfı İslam Ansiklopedisi (Ankara: TDV Yayınları, 2007), 34/65.

14 Abdurrahman Cami, Nefahattül Üns, çev. Lami Çelebi, yay. haz. Süleyman Uludağ Mustafa Kara (İstanbul: Marifet Yayınları, 1998), 699. 
Anadolu'da Halvetîyye adına kurulan ilk tekke Pir İlyas'ın Amasya'daki Gümüşlüoğlu Tekkesidir. Burada irşad faaliyetlerini sürdüren şeyhin vefatıyla yerine Şeyh Zekariyya postnişin olmuştur. ${ }^{15}$

Halvetîyye II. Bayezid devrinde Cemaliyye kolunun kurucusu Cemal Halvetî sayesinde İstanbul' da yayılmış, İmparatorluğun en etkin ve kabul edilir tarikatlarından biri haline gelmiştir. Özellikle Cemal Halvetî'nin Amasya'da hanedan mensupları ile kurmuş olduğu ilişki tarikatın tanınırlığını ve Osmanlı coğrafyasındaki etkinliğini zirveye çıkarmıştır. ${ }^{16}$

II. Bayezid döneminde, Cemâl Halvetî́nin Amasya'daki bağlantıları sayesinde tarikatın Osmanlı'nın başkentine taşınması Halvetîlik açısından bir milat olarak kabul edilmektedir. Burada elde ettiği nüfuz sayesinde Halvetîlik, Osmanlı kültür hayatına önemli katkılar sağlamış, bunun ötesinde siyasi ve idari konularda da etkin bir rol oynamıştır. İstanbul'daki ilk Halvetî tekkesi olan Koca Mustafa Paşa semtindeki Koca Mustafa Paşa Âsitânesi (Sümbül Efendi Dergâhı) bir merkez ya da karargâh görevi yapmış, tarikatın gerek İstanbul'da gelişmesinde gerekse Balkanlar'a taşınmasında önemli görevler üstlenmiştir. ${ }^{17}$

Halvetîliğin XV. yüzyıl ve daha sonraki yüzyıllarda Anadolu toplumunun dini ve sosyal hayatını en fazla etkileyen tarikat olmasında, Amasya'nın önemli bir rolü olduğu muhakkaktır. Tarikatın taşralı hüviyetinden kurtulup şehirli karakter kazanmasına Amasya'daki yaşadığı tecrübe ve burada kurduğu ilişkiler etkili olmuştur. Özellikle de payitahta sıçrayıp, merkezi yapıda en tesirli güç olması ve etkisini tüm Osmanlı İmparatorluğu'nda hissettirmesinde Amasya en güzel imkânları sunmuştur. ${ }^{18}$

Şehzade'nin İhvanları

İhvan; aynı şeyhe bağlı olan müritleri, aynı tarikatın veya tarikat kolunun mensuplarını ifade eder. Aynı tarikatın mensupları, kendi aralarında sırf Hak rızâsına dayanan samimi bir dostluğun gereklerini

15 Reşat Öngören, Osmanlılarda Tasavvuf (İstanbul: İz Yayıncılık, 2003), 28.

16 Zaur Şükürov, “Anadolu'da Faaliyet Gösteren İlk Halvetî Şeyhlerinden Muhammed Bahauddin Erzincani", Keşkül Dergisi, 23 (2012), 46-47.

17 Fatih Köse, "İstanbul' daki Halvetî Tekkelerine Dair", Keşkül Dergisi 23 (2012), 124.

18 Hasan Karataş, "The City as a Historical Actor: The Urbanization and Ottomanization of The Halvetîye Sufi Order by the City of Amasya in the Fifteenth and Sixteenth Centuries" (USD: University of California, Doktora Tezi, 2011), 59. 
yerine getirmenin yanı sıra tekke düzenine, tarikat kurallarına, şeyhin öğütlerine tam anlamıyla uyar, büyüklerini baba, akranını kardeş, küçüklerini evlât olarak görürler. Şeyh baba, müridleri onun evlâtlarıdır. Şeyhin eşi anne, birbirlerinin eşleri ise hemşiredir (bacı). Bu samimi dostluğun hâtırası ölümden sonra da devam eder. Vefat eden mensuplarının geride bıraktığı aile fertlerini korur, onlarla da dostça ilişkiler kurarlar. ${ }^{19}$

İhvan (dini grup kardeşliği) bağı tarikat mensuplarının kendi aralarındaki ilişkilerinde önemli bir yer tutar. Sıkı tarikat kuralları aynı tarikat içerisinde bulunan kişilerin tarikat yaşantısının dişındaki sosyal hayatlarında oluşan ilişkilerinde de birbirleriyle yakın münasebet kurmalarını öngörür. Hatta evlilik, alışveriş, aile dostluğu gibi sosyal ilişkilerde ihvanın öncelenmesi esastır. ${ }^{20}$

Dini grup kardeşliğinin bir görüntüsü olan bu yapı mürşit, mürit, ihvan üçlüsü çerçevesinde önemli sosyal fonksiyonlar üstlenmiş, tarikatın sosyal bağlarının güçlenmesini sağlamıştır. Başı sıkışan, zor durumda olan ihvanın yardımına koşmak, ona maddi ve manevi destekte bulunmak müntesiplere güven duygusu telkin etmiştir. Mürit hangi sosyal statüde olursa olsun mürşidin manevi murakabesi altında olup, ihvanlar tarafından da kardeşlik halkası içerisinde gerekli ilgi ve alakayı görmekte ve kendisine her konuda sahip çıkılmaktadır. Tasavvufi dini grupların içinde, hiyerarşi kişinin sosyal hayatındaki statüsüne göre değil, mürşit tarafından metodu belirlenen ve her talibin kişisel farklılıklarına göre değişen eğitimi sürecinde kat ettiği mesafeyle belirlenir ve onunla değer kazanır. Sadece manevi zenginliğin değer olarak kabul edildiği maddi açıdan sınıfsız bir topluluk olan tarikat gruplarına zengin fakir, yönetici memur, asker çiftçi gibi toplumun her kademesinden insan girebilmektedir. ${ }^{21}$

On beşinci yüzyılda Osmanlı devletinin sancak şehri Amasya'nın valisi Bayezid'in de bu sinıfsız topluluğun bir üyesi olduğunu görmekteyiz. Şehzade Bayezid Amasya'daki valilik yıllarında babası Fatih'in tepkisini çekecek ölçüde uygun olmayan bir yaşam tarzı sürmüş

19 Süleyman Uludağ, "İhvan”, Türkiye Diyanet Vakfi İslam Ansiklopedisi (Ankara: TDV Yayınları, 2000), 21/580.

20 Erhan Yetik, Tarikatlar ve Dini Hayat (Samsun: Kardeşler Ofset, 1996), 133.

21 Muammer Cengil, Tasavvufi Yaşantı (Ankara: Türkiye Diyanet Vakfı Yayın Matbaacılık ve Ticaret İşletmesi, 2008), 171-178. 
270 | A. BUDAK / Geçmişten Günümüze Dini Gruplar Olarak Tarikatların Siyasi Yapılarla İlişkileri olsa da ilimle iştigalini hiç kesmemiş hatta etrafına ilim adamlarını toplayarak onlara iltifat etmiştir. Onun bu yönü ile Osmanlı padişahları içerisinde en iyi yetişmiş ve kültürlü padişahlardan biri olduğunu söylemek mümkündür. ${ }^{22}$

O gençlik yıllarındaki yaşam tarzından dolayı babasının hışmına uğramış, etrafındaki bazı dostları hakkında ölüm emri bile çıkarılmıştır. Şehzadelik yıllarında böyle bir yaşam tarzı olmasına rağmen çevresindeki dini gruplarla iyi ilişkiler kurmuş, onlara iltifat etmiş, hayır dualarını istemiştir. Bayezid tarikat gruplarıyla iyi ilişki kurmanın ötesinde çevresinde bulunan bazı şeylerden el alıp onlara intisap da etmiştir. ${ }^{23}$

Şehzade, konağında misafir edecek kadar samimi olduğu, Bayramiyye Tarikatı şeyhlerinden İskilipli Şeyh Muhiddin Yavsi'ye (ö. 910/1514) intisap etmiştir. Onunla olan münasebetini Sultan olunca da devam ettirmiş, İstanbul'a davet ederek onun adına bir tekke yaptırmış, Bayramiyye'nin buradaki ilk tekkesi sayesinde tarikatın İstanbul'da örgütlenmesine yardımcı olmuştur. Bayezid'in intisap ettiği şeyhlerden bir diğeri de Bayramî şeyhi Baba Yusuf'tur (ö. 917/1512). Sultan olunca onu İstanbul' da yaptırdığı camide vaaz etmesi için çağırmış, bu vaazlara kendisi de iştirak etmiştir. ${ }^{24}$

Şehzadenin intisap ettiği şeyhlerden asıl öne çıan isim Halvetî Şeyhi Cemal Halvetî́ dir. O sıkıntılı anlarında şeyhin duasını talep etmiş, maddi ve manevi her türlü sıkıntısında onun yanında yer alarak yardımda bulunmuştur. Oğlu Şehzade Ahmed'in eğitimini kendisine bırakacak kadar ona güvenmiştir. Yakın ilişkileri tahta geçince de devam etmiş, Koca Mustafa Paşa'daki dergâhta şeyhi ziyarete gitmiştir. İstanbul'da meydana gelen veba salgınından kurtulmak için şeyhi dua etmesi için Kâbe'ye dervişleriyle birlikte göndermiştir. ${ }^{25}$

Bu yönüyle Bayezid bir mürşidin murakabesindeki mürid ve aynı zamanda dâhil olduğu tarikat içerisindeki diğer bağlıların da ihvanı olmuştur. Bizim asıl üzerinde duracağımız konu Cemal Halvetî’nin müridinin sultan olması için verdiği siyasi destek, gösterdiği büyük çaba ve ihvanın sonsuz desteğidir.

22 Yılmaz Öztuna, Devletler ve Hanedanlar (Ankara: Kültür Bakanlığı Yayınları, 1990), 2/136.

23 Şapolyo, Mezhepler ve Tarikatlar Tarihi, 501.

24 Bk. Öngören, Osmanlılarda Tasvouf, 246-258.

25 Bk. Öngören, Osmanlılarda Tasvvuf, 246-258. 


\section{İhvan Dayanışması}

İlginç olan ve akla gelen soru, Şehzadenin Amasya yıllarında özel yaşantısı konusunda babasından ciddi uyarı alacak ölçüde serkeş bir hayat yaşaması ve çevresinde Sultan'ın haklarında ölüm kararı verebildiği sakıncalı arkadaşları olmasına rağmen, tasavvuf gibi manevi disiplinin yoğun şekilde uygulandığı yaşam tarzının kurumsallaşmış yapısı olan tarikata dâhil olmasının ve bir şeyhe bağlanıp mürit olmasının altında yatan temel sebepler nelerdir? Hangi sâikler Bayezid'i böyle bir tercihe zorlamış olabilir?

Aralarındaki karakter uyuşmazlığı nedeniyle Şehzade'nin babasıyla olan ilişkilerinde destek alabileceği başka kişilerin veya kurumların arayışı içerisinde olduğu görülmektedir. Tarihçilerin ortaya koyduğu tespitler gösteriyor ki Şehzade bazıları temel unsurlar olmak üzere pek çok konuda babasıyla anlaşamıyordu.

Başta karakterleri itibariyle birbirlerinden farklı olan Şehzade ile Sultan, olayların çözümünde uygulanacak metotlar konusunda da birbirleriyle uyum içerisinde hareket edemiyorlardı. Fatih'in sert, kararl, ben merkezli, çabuk usanan karakterinin yanında Şehzade'nin, cevval olmayan, rahat, ihtiyatlı, barışsever, mümkün olduğu kadar kan dökmeden uzak tavrı, sanata düşkün yönü, ağır başlılığı, savaştan çok sulhu esas alan yaklaşımı baba ile oğul arasında karakter uyumsuzluğu ortaya çıkarmaktaydı. Bu temel karakter ayrılığı Fatih gibi otoriter bir şahsiyet tarafından kabul edilebilir ve hoş görülebilir olamayacağ oğlunu pek çok zaman zorlayarak belki de alenen uyararak kendisine tabi olmasını istemesi Bayezid'i kendini hem rahatlatacak hem de güvende hissettirecek arayışlar içerisine sokmuş olabilir. ${ }^{26}$

Bayezid'in sufi gruplariyla bu kadar yakın olmasının sebeplerinden biri de Fatih'in ölümünden sonra yerine geçecek şehzadenin kim olacağı konusundaki tartışma ve siyasi çekişmeler olduğu görülmektedir.

İstanbul'daki siyasi ortam bu konuda gergin ve belirsiz olduğu gibi asker ve yönetici sınıflar ayrışmış olup gizli bir mücadele içinde idiler. Bir grup Amasya'daki Bayezid'in saltanata geçmesi için gayret ederken diğer bir grup da Cem konusunda kulis yapmaktaydılar. Zahiri görüntü Fatih'in oğlu Cem'i daha çok sevdiği ve Sadrazam Karamanî

26 İsmail Hakkı Uzunçarşılı, Osmanlı Tarihi (Ankara: Türk Tarih Kurumu Yayınları, 1988) 2/150, 239. 
Mehmet Paşa'nın telkiniyle onu tahta geçirme konusunda daha istekli olduğudur. Ayrıca çıkarılan Kanunnâma-i Âl-i Osman'da şehzadelerin lakabı yazılırken isim olarak Cem'in zikredilmesi ve bu konuda sultanın herhangi bir müdahalede bulunmaması Cem'i bir adım öne çıkarıyor ve saltanat konusunda daha avantajlı kılıyordu. ${ }^{27}$

Şehzade, Amasya'da eğlenceye düşkün bir hayat sürdüğü iddiasıyla babası tarafından tahkikata uğramış, sonuçta İstanbul'dan gelen ferman ile üç yakın arkadaşı; Mahmut Paşa, Taci Bey, Abdurrahman Efendiler idam cezasına çarptırılarak, etrafındaki adamları da azledilmişti. Bayezid, Taci Bey ve Abdurrahman Efendiyi Amasya'dan kaçırarak ölümden kurtarmış fakat Mahmut Paşa idam edilmişti. Babası ile böyle bir gerginlik de yaşayan Şehzade saltanat yarışında pekte şanslı gözükmüyordu. Gerçi aleyhine olan bu tahkikat konusu onu gözden düşürmek için Karamanî Mehmed Paşa tarafından organize edilmiş olsa da neticede İstanbul'daki konumunu ciddi derecede sarsmıştı. İshak Paşa ve başında bulunduğu Yeniçeriler kendi tarafında olmasına rağmen Sadrazamın emrindeki sipahiler de kardeşi Cem'i destekliyordu. ${ }^{28}$

Aleyhine gelişen şartlar ve Karamani Mehmed Paşa'nın babası üzerindeki etkisinin saltanat yolunda Şehzade'ye ciddi engeller çıkardığı görülmektedir. $\mathrm{Bu}$ durumda Bayezid'in durumunu güçlendirecek, kardeşine karşı kendisini avantajlı duruma geçirecek arayışlar içinde olması muhtemeldir. Anlaşılan o ki Amasya ve çevresinde bulunan sufi gruplar ve etkin faaliyetleri Bayezid'in dikkatini çekmiş, onlarla iyi ilişkiler kurma konusunda özel gayret göstermiştir. Döneminin sivil toplum kuruluşları olarak kabul edilen tarikat zümreleri, halk tarafından saygı görürken yöneticilerin de ilgi ve alakasına mazhar olmuşlardı. Bu durum Osmanlı toplum yapısında tarikatları ve onların liderlerini etkin hale getirmiş, pek çok fonksiyonu yerine getirmelerine yol açmış, desteklerini alan yöneticilere de avantajlar sağlamıştır. ${ }^{29}$

Bayramiyye ve Halvetiyye tarikatlarına girerek onların ihvan gruplarına dâhil olan Şehzade yukarıda bahsettiğimiz ihvan hukukunun

27 Uzunçarşıll, Osmanlı Tarihi, 2/149.

28 Abdizade Hüseyin Hüsameddin, Amasya Tarihi, yay. haz. Mesut Aydın - Güler Aydın (Amasya: Amasya Belediyesi Kültür Yayınları, 2007), 3/144-146.

29 Ahmet Yaşar Ocak, Osmanlı Sufiliğine Bakışlar (İstanbul: Timaş, 2011), 95-96. 
gereği olarak onların maddi ve manevi desteğini talep etmiş, murakabelerine girdiği şeyhlerinin hem hayır dualarını hem de fiili desteklerini istemiştir. Bu konuda gerek şeyhleri gerekse ihvanları Bayezid'i hiçbir zaman hayal kırıklığına uğratmayarak, ona olan desteklerini her yerde ve zamanda göstermişlerdir. Anadolu'daki yaygın tekke ağları sayesinde en ücra yerlere kadar ulaşarak geniş kitleleri bilgilendirme ve etkileme kabiliyetine sahip olan bu yapilar, Şehzade'nin saltanata geçmesi konusunda ciddi bir kamuoyu oluşturmuşlardır. Bu durum Bayezid'in ittifak arayışlarında kendisine büyük avantaj sağlamış, dezavantajlı olduğu durumları nispeten ortadan kaldırmıştır. ${ }^{30}$

Şehzade İstanbul'daki siyasi ortamı dikkatlice takip etmekle beraber kardeşi Cem'in faaliyetlerinden de haberdardı. Cem'in tarafını tutan Karamanî Mehmed Paşa'nın İstanbul'daki Zeyniye Şeyhi Şeyh Vefa ile yakın ilişki içinde olduğu, saltanat konusunda Cem'e destek verdiği ve bu konuda Zeynilerin faaliyet içerisinde oldukları Bayezid'in kulağına ulaşmıştı. O da Amasya' daki sufi çevrelerinden kardeşiyle olan mücadelede kendine destek vermeleri için yardım istedi. Görülüyor ki Şehzadenin yardım çağrısına kulak veren ve en aktif desteği sağlayan dini grup Halveti'ye Tarikatı ve onun Amasya'daki şeyhi Cemal Halvetî oldu. ${ }^{31}$

\section{Şeyh ve Mürid}

Dini gurupların en önemlilerinden olan tarikat kurumlarını ortaya çıkaran tasavvufi düşünce yapısına göre rehbersiz hiçbir şey yapılamayacağı için manevi eğitim adına kendisini bu yola tabi kılan müridin her şeyden önce bir şeyhe tabi olması gerekir. Bu bağlılık sorgusuz bir itaat ve tam bir teslimiyet gerektirir. Çünkü şeyh manevi âlemde yapılacak olan yolculuğun yegâne rehberi olup, kendi yaşadığı tecrübeyi talibine aktarma göreviyle mükelleftir. ${ }^{32}$

Dini grupların liderleri karizmatik kişiler olarak kabul edilmişlerdir. Çünkü karizmanın tarifinde olduğu gibi onlar olağan üstü yeteneklere sahip kişilerdir. Bu üstün özellikler ister gerçek ister yakıştırma, isterse şeyhin uçurulması hadisesi olsun neticede bir kitle

30 Abdulhamit Budak, Bir Şehir Bir Tarikat, Amasya ve Halvetilik (Amasya: Amasya Belediyesi Kültür Yayınları, 2016), 138-139.

31 Öngören, Tarihte Bir Aydın Tarikatı Zeyniler (İstanbul: İnsan Yayınlar, 2003), 142-143

32 Erol Güngör, İslam Tasavvufunun Meseleleri (İstanbul: Ötüken Yayınları, 2004), 81. 
tarafından varlığına inanç varsa o kitleyi etkileyici bir yönü olması hasebiyle sosyolojik açıdan karizma olarak kabul edilir. Karizmanın doğal sonucu karizmatik otoritedir. Bu otorite türü, yönetilenlerin belli bir kişide olağan üstü niteliklerin var olduğuna inandıkları için itaat ettikleri hâkimiyeti ifade eder. Bu hâkimiyet maddi veya manevi kaynaklardan ortaya çıkmış olabilir. Karizmatik lider bu karizmasını dünyevi konularda öne çıkan üstün özelliklerle pekiştirmek zorundadır. Şayet kazandığ 1 üstünlük vasfını yenileyerek devam ettiremezse bir süre sonra karizmasından dolayı etrafında toplanan kitle dağılır ve lider otoritesini kaybeder. Bundan dolayı karizmasını siyasetteki başarısından alan politik lider seçimleri kazanmalı ve başarısını devam ettirmeli, karizmasinı zaferlerinden elde eden komutan yeni zaferler kazanmalıdır. Bu durum karizmanın üzerinde her daim bir baskı unsuru olarak var olur ve onu sürekli hareket etmeye zorlar. ${ }^{33}$

Şeyhler de kendilerinde var olduğuna inanılan üstün manevi niteliklerini bağlı olanları nezdinde muhafaza edebilmek için belli olaylarla onları pekiştirme ihtiyacı hissederler. Bu yukarıda da değinildiği gibi daha çok dünyevi konularda olmuş ve talibin veya cemaatin bir ihtiyacını karşılamıştır. Her ne kadar şeyhler manevi alandaki eğitim ve terbiyeyle taliplerine yol göstericilik konusunda belli otoriteye sahip olduklarını söyleseler de ortaya çıkan değişik ihtiyaçlardan dolayı başka konularda da kendilerinden rehberlik beklene gelmiştir. Bu ihtiyaçlar ekonomik, eğitim, aile gibi sosyal yapılardan ortaya çıktığı gibi siyasi alanda da kendini göstermiştir. Özellikle yönetici vasfında olanlar veya yönetimi ele geçirmek için mücadele edecek müritler, şeyhlerinden belli konularda taleplerde bulunmuşlar ve onların maddi ve manevi yardımlarını istemişlerdir. Yukarıda bahsettiğimiz otoritenin sorgulanmaması adına şeyhler de bu taleplere uzak kalamamıs, isteyerek ya da istemeyerek siyasi çekişmelerin içinde kendilerini bulmuşlardır. ${ }^{34}$

Cemal Halvetî, Anadolu'daki tasavvufi çevre tarafından büyük saygı gösterilen, sahip olduğu özellikler açısından da Tarikatı içerisinde mühim bir yere sahip olan karizmatik bir şeyhtir. O halveti tarikatının en önde gelen şeyhlerinden olup tarikatın Anadolu'da yayılması ve

33 Max Weber, Sosyoloji Yazıları, çev. Taha Parla (İstanbul: Hürriyet Vakfı Yayınları, 1986), 252-253.

34 Ocak, Osmanlı Sufiliğine Bakışlar, 74, 75. 
İstanbul'a taşınmasında büyük görevler üstlenmiştir. Halvetîliğin Osmanlı coğrafyasındaki en yaygin tarikat olmasında Şeyhin yetiştirdiği halifelerinin büyük etkisi olmuştur. Şeyhin yetiştirdiği meşhur halifeleri şunlardır: Sümbül Efendi, İdris Efendi, Cemal Efendi, Kasım Efendi, Alaaddin Uşşaki, Hayrettin Tokadi, Üveys Dede, Cemşahı Karamani, Sinanı Erdebili, Muslihuddin Efendi, Selahaddin Efendi, Bayezid Halife, Ali Dede, Davut Dede. Halvetîliğin yalnız bir tarikat olarak dini yaşantıda değil, Osmanlı toplum hayatında da yönlendirici ve etkileyici bir dini grup olmasında onun tesiri çok büyüktür. ${ }^{35}$

Cemal Halvetî tasavvufi yönünün yanında güçlü bir edebi kişiliğe sahiptir. O, Arapçayı ilim dili olarak kullanabilen bir düşünür ve âlim, Türkçe yazdığı şiirleriyle değerli bir şairdir. Onun daha çok mesnevi tarzında kaleme aldığı şiirlerinden oluşan manzum eserleri oldukça önemlidir Cemal Halvetî, Halvetî Tarikatı'nın İstanbul'da en büyük temsilcisi olması, döneminin sosyal hayatına yön veren bir ilim ve düşünce adamı olmasından dolayı ve kaleme aldığı eserleriyle, Türk kültür tarihinin önemli şahsiyetlerinden birisi olarak bilinir. Hediyyetü'1 Ârifîn'de Şeyhin on altı eserinin olduğu bilgisi verilmektedir. ${ }^{36}$

İlmi, edebi ve tasavvufi alanlardaki güçlü şahsiyetiyle karizmatik liderlik görüntüsü çizen bu şeyh çevresindeki pek çok insanı etkilemiş ve kendisine intisap etmelerine neden olmuştur. Tabi ki bu ilgi ve alakadan siyasiler de etkilenmiş ve onun geniş alanlara yayılan mürit ve tekke ağının gücünden istifade etmek istemişlerdir. Dini grup, siyaset ilişkilerinde gözlemlenen temel sonuçlardan birisi de yöneticilerin kendi meşruiyetlerini güçlendirmek ya da diğer rakip siyasi oluşumlarla olan mücadelelerinde kendilerini güçlü kılmak için ittifaklara her zaman sıcak bakıp gerek şeyhin gerekse dini grubun etkisini her zaman kullanmış olmalarıdır. ${ }^{37}$

35 Muharrem Çakmak, Cemal Halveti, Hayatı, Eserleri, Tasavvufi Düşüncesi ve Cemâliye Kolu (Erzurum: Atatürk Üniversitesi, Doktora Tezi, 2000), 51-59.

36 İsmail Paşa, Hediyyetü'l 'Ârifinn (Beyrut: Dârü'-l kütübü'l- 'ilmiyye, 1992), 5/217. Eserleri şunlardır: Esrârü'l-vudû', Eyyühe'l-1hvân, Tefsîrü'l-ayeti'l-kürsî, Tefsîrü'ssûreti'l-Fatiha, Tefsîr min Sureti'd-duhâ İlâ âhiri'l-Kurân, Câmi'atü'l- esrâr ve'1garâ'îb, Cenknâme, Cevâhirü'l-kulûb, Risâletü'l-etvâr, Risale't-teşrîhiyye, Errisaletü'l-fakriyye, Er-risaletü'l-kevseriyye, Zübdetü'l-esrâr, Şerhü kelimeti Haydarü'l-kerrâr, Şerhü'l-erba'în Fi'l-hadîs, Şerhü Erba'îni'l-kudsiyye, Şerhu kelimâti's- Sıddîkı'l-Ekber.

37 Ejder Okumuş, Toplumsal Değgişme ve Din (İstanbul: İnsan Yayınları, 2012), 80. 
Biz bu olguyu Şehzade Bayezid'in Osmanlı saltanatını ele geçirmek için yaptığı mücadelede Amasya'daki Halvetî Tarikatı'nın şeyhi ve onun elinde bulundurduğu gücü nasıl kendi lehine yönlendirip başarı ile sonuçlandırdığını o dönemde meydana gelen tarihi olaylar ile ele almak istiyoruz. Olayları incelerken daha çok tasavvufi muhitin konu ile ilgili anlatımlarını esas alacağımız için bu bizi onların tasavvuf liderlerinin hayatlarını anlatan menakıp kitaplarına götürecektir. Menakıp kitapları şeyhlerin olağan üstü hayat hikâyelerini anlatan, mistik zihin ürünü, efsanevi anlatım üsluplarına sahip eserler olarak görülür. Fakat aklın rehberliği, insan psikolojisi, sosyal psikoloji, tarih bilgisi, topluma hâkim olan kanunlar gibi kriterlere dikkat edenler, efsanelerden, masallardan, menkıbelerden tarihi, dini, toplumsal tespit ve sonuçlara ulaşabilirler. Bu açıdan bazı şeyhlerin hayatlarıyla ilgili bilgiye ve bazı tarihi sonuçlara menakıp kitaplarına başvurarak ta ulaşmak mümkün olur. ${ }^{38}$

Geleneksel dönemlerde, tarihçilerin yönetici sınıfının yanında yer alma veya rekabet içinde olunan devletin karşısında bulunma gibi taraf olma nedenleriyle tarihi gerçekleri kitaplarında objektif olarak ortaya koyamadıkları bir gerçektir. Aynı zamanda onların tarih anlatımı, resmi bakış açısının etkisinde olduğu için daha çok saray ve sultan çevresindeki olayların aktarımı şeklinde olmakta, bu da dönemin diğer toplumsal ve kültürel unsurlarını göz ardı etme sonucunu doğurmaktadır. İşte menakıpnameler resmi tarih anlayışı dışında bağımsız, sivil bakış açısını da ortaya koyduğu için kültür tarihi ve sosyoloji bilimi açısından önemli kaynaklardan biri olarak kabul edilmektedirler. ${ }^{39}$

\section{Saltanata Giden Yol}

Yukarıda bahsedildiği gibi babasıyla olan ilişkilerindeki gerginlik, Karamanî Mehmet Paşa'nın aleyhindeki faaliyetleri ve Konya'daki Cem Sultan'ın saltanat için girişimleri Şehzadeyi ciddi derecede bunaltmış ve arayışlar içine sokmuştu. Bu haldeki Şehzade kendini teselli ve rüyalarını tabir etmesi için sık sık Kapıcıbaşı Hacı Mustafa Ağa aracılığıla Şeyh Cemal Halveti'ye başvuruyor, onun manevi

38 Süleyman Uludağ - Mustafa Kara, Nefahat'ü-l Üns Tercümesi, Evliya Menkıbeleri (İstanbul: Marifet Yayınları, 1998), 28-29.

39 Ahmet Yaşar Ocak, Kültür Tarihi Kaynağı Olarak Menakıbnâmeler (İstanbul: Türk Tarih Kurumu Yayınları, 1997), 65-69. 
tasarruflarıyla rahatlıyordu. Şeyhin müridlerinden olan Ağa, şehzadenin musahibi yani yakın dostu, sırdaşı ve ihvanı idi. ${ }^{40}$

Anlaşllıyor ki Şeyhle, Şehzadenin hasbihalleri sadece manevi alanla ilgili telkinlerden ibaret olmayıp, ülkenin gündemini alakadar eden konuları da içeriyordu. Bayezid, ağa aracılığıyla dua ve himmet etmesi için şeyhe bir miktar para gönderiyor, dileğinin ne olduğunu sorarsa şeyh tarafından malum olduğunu söylüyor. Şeyh de sabah cevabı vereceğini söyleyerek istek konusunda herhangi bir itirazda bulunmuyor ve ağayı gönderiyor. Bundan da anlaşılıyor ki iki taraf ta konu hakkında daha önce istişarelerde bulunmuşlar ve çözüm konusunda değerlendirmeler yapmışlar. Muhtemeldir ki Konya ve İstanbul bağlamında şeyh çalışmalarını başlatıp gerekli görüşmeleri yapmış olmalı. Çünkü Karamâni Mehmet Paşa'nın şehzade ile ilgili olumsuz düşünceler beslediğini, Karaman velilerinin Cem'in etrafında toplanıp ona saltanat yolunda yardımcı olduklarını ve İstanbul'da Şeyh Vefa'nın Karamâni Mehmet Paşa'yı desteklediklerini sabah olunca ağaya aktarıyor ve bir çözüm bulacağını ifade ediyor. ${ }^{41}$

Aslında Şehzadenin isteği çok açık ve nettir. Saltanatı yolunda büyük bir engel olarak gördüğü Sadrazamı ortadan kaldırmak istemektedir ve bu konuda da şeyhin desteğini talep etmektedir. Bu istek herhangi bir şaşkınlık ve itiraz doğurmamış, gereğinin yapılacağ konusu karşı tarafa iletilmiştir. Hatta şeyhin dediğine göre sufiler yani Bayezid'in ihvanları çalışmalara başlamış, bir açık yol bulur gibi de olmuşlardır. Şeyh ağaya otuz üç gün içinde Şehzade'ye büyük bir haberin geleceği müjdesini vermiş, bu süre içinde Sadrazamın ortadan kalkacağına işaret etmiştir. Tabii ki Osmanlı Devleti'nin sadrazamını ortadan kaldırmak gibi büyük bir eylemi gerçekleştirmek basit bir konu olmayıp siyasi ve toplumsal pek çok ittifakı gerektirmektedir. ${ }^{42}$

Nefahat'ta Lami Çelebi, olayı Yavuz Sultan Selim'in kazaskerlerinden Tacî zâde Cafer Çelebi'nin ağzından anlatır ve Şehzadenin isteğini götürenin Mustafa Ağa değil babası Tacî Bey olduğunu söyler. Taci Bey Sadrazamın ortadan kaldırılması ile ilgili

40 Mahmud Cemaleddin el-Hulvî, Lemâzât-ı Hulviyye el-Lemeât-ı 'Ulviyye, haz. Mehmet Serhan Tayşi (İstanbul: Semerkand Yayınları, 2013), 412.

41 Lâmî Çelebi, Nefahat'l-üns Tercüme ve Şerhi, haz. Süleyman Uludağ - Mustafa Kara (İstanbul: Marifet Yayınları, 1998), 708.

42 Hulvi, Lemazât, 413. 
278 | A. BUDAK / Geçmişten Günümüze Dini Gruplar Olarak Tarikatların Siyasi Yapılarla İlişkileri talebin kabul olduğunu Şehzade'ye aktarınca utandığını, yüzünün kızardığını, kimsenin helak olmasına istekli olmadığını, fakat sadrazamın sürekli kendisiyle ilgili babasını doldurduğunu başka çıkar yolunun olmadığını aktarır. ${ }^{43}$

Şeyh manevi âlemde Karaman evliyası ile mücadeleye girer ve Cem'in halli için harekete geçer, fakat görür ki Karaman velileri Cem'i korumaktadırlar ve şeyhin hamlesine karşı hamlede bulunarak şeyhe ve Bayezid'e kast ederler. Şeyh onların bu hamlesinden kendini ve şehzadeyi korur ama kızı bu girişimin neticesinde atılan ateşten isabet alarak hastalanır ve bir müddet sonra da vefat eder. Amasya şeyhleri ile Karaman şeylerinin arasında canlara kast eden ve bir çocuğun ölümüyle sonuçlanan bu çetin mücadeleden anlaşılıyor ki taraflar ciddi şekilde birbirlerine hasım durumdadırlar. Bu mücadelenin sadece manevi ortamda olmadığ1 ve maddi dünyada tarafların mücadele ettikleri ve büyük bir rekabet içinde oldukları anlaşılmaktadır. Muhtemeldir ki taraflar pek çok defa ya bir araya gelerek ya da birbirlerine haberciler göndererek konuyu ele alıp tartışmışlardır. ${ }^{4}$

İlk girişiminden başarısız olan şeyh bir müddet konuyla ilgilenmemiş fakat şehzadenin ısrarları üzerine tekrar girişimlerde bulunmuş ve Karaman velileriyle yine karşı karşıya gelmiştir. Anlaşılıyor ki bu defa görüşmeler manevi âlemde olmamış, Karaman velileri Amasya'ya gelerek neden bu kadar ısrar edildiğini ve açık olarak maksadın ne olduğunu sormuştur. Karaman velilerinin Amasya'ya kadar gelmeleri, Şehzade'nin Şeyh'ten tekrar girişimde bulunmasını istediği esnada Bayezid'in de o mecliste olduğu bilgisi, gösteriyor ki aradaki buzlar erimiş ve konuşulabilecek ortak paydalara da ulaşılmıştır. ${ }^{45}$

Bu toplantıda Şeyh'in ve Şehzade'nin Cem ile ilgili herhangi bir talepte bulunmamaları ve isteklerinin ne olduğu sorulunca problemin Karamânî'nin olduğunun söylenmesi ilginçtir. Çünkü yukarıda da görüldüğü gibi ilk hedef Cem olmuş, fakat velilerin ona sahip çıkmasıyla bu amaç yerine getirilememiştir. Karaman velileri Cem'in yanında durarak ona desteklerini sürdürmüşler ve bir zarar verilmemesi

43 Nefâhat, Lâmi Çelebi, 708.

44 Mecdî Efendi, Tercüme-i Şakayık-ı Nu'maniye (İstanbul: Darüt Tıbaatül Amire, 1269), 285.

45 Mecdî, Tercüme-i Şakayık-ı Nu'maniye, 285. 
konusunda da ısrarlarını devam ettirmişlerdir. Muhtemelen bununla ilgili tartışmalar toplantının ana konusu olmuştur. Mücadelenin merkezine Karamâni Mehmet Paşa oturmuş ve onun vakıflar ile ilgili uygulaması sebep gösterilerek ona verilen destekten vazgeçilmesi istenmiştir. Karamanî hayır sahiplerinin vakıflarını bozmakla ve mülküne geçirmekle itham edilmiş, bunun üzerine Şeyh vefa hariç bütün Karaman velileri ondan desteğini çekerek şeyhin ve Bayezid'in isteğini yerine getirmişlerdir. ${ }^{46}$

Burada Anadolu'daki meşayihi rahatsız eden ve Karamanî'nin aleyhine ittifak ederek halli için Cemal Halvetî ile iş birliği etmelerine neden olan vakıflar meselesine değinmek gerekir. Fatih'in aşırı savaşçı bir politika izlemesi ülkeyi yormuş, sınırsız iktidar gücü ve sert mizacıyla, kışın bile devam ettirdiği savaşlarda yeniçeriler yıpranmış, ordu asileşmişti. Fetihleri devam ettirebilmek için yeni vergiler konulmuş, akçenin gümüş değeri birçok kez düşürülmüş, çok sıkı bir mali denetim uygulanmıştır. Bunun yanında asker ihtiyacını karşılayabilmek için tımarlı sipahi sayısını artırmak isteyen Fatih, emlak ya da vakıf haline dönüşen yirmi bin kadar çiftlik ve köyü devlet kontrolüne alıp özel mülkiyet ve vakıf statüsünden çıkarmış ve tımar olarak askere dağıtmıştır. Bu tedbirler özellikle etkili Türk ailelerini, ulemayı ve vakıflardan başka geliri olmayan şeyhler ve dervişleri ciddi derecede etkilemiş, bu sinıfların büyük hoşnutsuzluğunu doğurmuştu. Fatih'in bu uygulamasına Cem Sultan büyük destek vermiş, fakat Bayezid bu kanunu kendi hâkimiyet alanları olan Amasya, Tokat ve Trabzon'da uygulamaktan kaçınmıştı. Bu durum uygulamadan rahatsız olanların Bayezid etrafında toplanmasına sebebiyet vermiştir. İşte bu sebepten dolayı vakıflara müsadere uygulamasından rahatsız olan Karamanlı şeyhler ve diğer Anadolu meşayihi, Karamanî'nin ortadan kaldırılması konusunda Cemal Halvetî̀ nin attığı adımları desteklemişler ya da en azından sessiz kalmışlardır. ${ }^{47}$

46 Hoca Sadettin Efendi, Tacü't-Tevarih, sad. İsmet Parmaksızoğlu (İstanbul: Kültür Bakanlığı Yayınları, 1979), 5/207.

47 Halil İnalcık, Osmanl İmparatorluğu Klasik Çă̆ (1300-1600), çev. Ruşen Sezer (İstanbul: Yapı Kredi Yayınları, 2003), 35. Ayrıca bk. Halil İnalcık, "II. Mehmet", İslam Ansiklopedisi (Ankara: MEB Yayınları, 1997) 7/533.

Aşıkpaşazâde'nin Karamânî (Nişancı) Mehmet Paşa hakkında bilgi verirken kullandığı ifadeler o dönemde Sadrazamın halk nazarındaki durumunu daha iyi anlatmaktadır. “Nesli belli değildir. Allah'ın kullarının malına, kanına ve ırzına el 
280 | A. BUDAK / Geçmişten Günümüze Dini Gruplar Olarak Tarikatların Siyasi Yapılarla İlişkileri

İstanbul'daki Zeyniye şeyhi Vefa (ö. 896/1491) hariç diğer meşayihin desteğini alan Cemal Halvetî Sadrazam'ın ortadan kaldırılması için çareler aramaya başlamıştı. Fakat Şeyh Vefa'nın yazdığı ve Sadrazam'ın kavuğunda sakladığı vefk ${ }^{48}$ onu her türlü beladan koruyor ve Şeyh'e tasarruf noktasında fırsat vermiyordu. Bu sırada Fatih yeni bir sefer için Üsküdar'a geçmiş fakat burada hastalanarak vefat etmişti. Karamânî Mehmet Paşa, Sultan'ın vefatını yeniçerilerden saklayarak iki şehzadeye de sultanın öldüğünü bildiren haberciler gönderip onları İstanbul'a davet etti. Sultan'ın nâşının karşı tarafa geçirilmesi sırasında meydana gelen olaylar ile halkın ve yeniçerilerin Sultan'ın ölümünü her nasılsa öğrenmeleri üzerine çıkan isyanlarla sadrazam çok yıprandı ve kavuğunun içinde taşıdığı vefkin bir kısmı sslanarak tahrip oldu. Sadrazam, Şeyh Vefa'nın adamlarından birini vefki tamir etmesi için şeyhe gönderdi. (Bu durum sadrazam ile Şeyh Vefa arasındaki olumlu münasebetin devam ettiğinin de göstergesidir. Çünkü bazı kaynaklar Şeyh Vefa'nın da Cemal Halvetî tarafından ikna edildiği ve sadrazama muhalif olanlara katıldığ 1 bilgisini vermektedir) ${ }^{49}$ Sadrazamın vefkin korumasından çıkması Cemal Halvetî'ye istediği fırsatı verdi ve Karamânî Mehmet Paşa yeniçeriler tarafından öldürüldü. Ya da Cem'i tahta taşımak isteyen ve bu konuda büyük gayret gösteren Sadrazam, içlerinde Halvetîlerinde bulunduğu Bayezid ittifakı tarafından öldürülerek şehzadeye saltanat yolu açılmış oldu. ${ }^{50}$

uzatmıştı. Nerede uygunsuz işler varsa onun icadıdır. Osmanlı memleketinde İslam hukukuna uygun vakıfları ve mülklerin hepsinin şartlarını bozdu. Gelirlerini padişahın hazinesine getirdi. Sorana da "Bunlar mensuhtur (hükmü kalkmıştır.)" dedi. Bazısını da tımar olarak verdi. Ben kendisine "Şer' -i Muhammedi ile olan vakıflar ve mülkler nasıl mensuh olur (hükmü ortadan kalkar) Hazret-i Muhammed, peygamberlerin sonuncusudur. Ondan sonra bir peygamber daha gelmemiştir ki onun şeriatını mensuh etsin." dedim. Bana cevaben "Sana ait olan neyini aldılar ki böyle konuşuyorsun." dedi." Aşıkpaşazade, Osmanoğullarının Tarihi, çeviri ve günümüz diline aktarım, Kemal Yavuz - M. A. Yekta Saraç (İstanbul: K Yayınları, 2003), 290.

48 Vefk; Arapça, muvafakat, uygunluk, başarı vs. gibi anlamları olan bir kelime. Bir kişinin isteğine uygun olarak hazırlanan dua, harf, muska ve hamail için vefk tabiri kullanilır.

49 Bk. Hulvî Lemâzât, 414.

50 Emine Karahan, Yûsuf Bin Yâkub'un Menâkıb-ı Şerîf ve Tarîkatnâme-i Pîrân ve Meşâyih-i Tarîkat-ı Aliyye-i Halvetiyye Adlı Eserinin Incelenmesi (İstanbul: İstanbul Üniversitesi, Sosyal Bilimler Enstitüsü, Yüksek Lisans Tezi, 2016), 136. 
Zaten Şehzade Cem'e gönderilen ulak yolda yakalanarak Bayezid taraftarlarınca öldürülünce, Cem babasının ölümünü abisinden sonra haber almıştır. Bu gecikme Cem'e saltanat kapısını kapatmış, abisinin ondan önce İstanbul'a ulaşmasına yardımcı olmuş ve tahta geçmesini sağlamıştır. ${ }^{51}$

Şeyhin otuz üç gün sonra meydana geleceğini müjdelediği olayın ne olduğu anlaşılmış oldu. Sultan Fatih vefat etti (ya da öldürüldü) saltanat boşaldı, şehzadenin bir numaralı düşmanı Karamânî Mehmet Paşa öldürüldü ve saltanatın önündeki en büyük engel kaldırılmış oldu. Sadrazamın öldürülmesi sadece şeyhin manevi ya da maddi imkânlarını kullanarak tek başına gerçekleştirdiği bir eylem olmayıp sıradan bir yeniçeri nümayişinin neticesi de değildi. Anlaşılıyor ki Bayezid'in saltanata geçmesi için askerlerden, vezirlerden, âlimlerden, büyük Türk ailelerinden, şeyhlerden meydana gelen büyük bir koalisyon oluşmuş ve her bir grup üzerine düşeni yaparak sonuca ulaşılmıştı. Ama bu konuda şehzadenin ihvanları Halvetîler ve onların şeyhi Cemal Halvetî'nin ölüm gibi pek çok riskleri de göze alıp büyük bir mücadele örneği gösterdikleri anlaşılmaktadır. Bazı değerlendirmeler de Halvetîlerin Fatih'in öldürülmesinde önemli roller üstlendiğine dair belirtilerin olduğu ileri sürülse de bu konu yeterli tarihi delillere dayanmamaktadır. ${ }^{52}$

Sultan Bayezid tahta oturmasından birkaç sene sonra şeyhi İstanbul'a davet etmek için eski kapıağası, yeni veziri Mustafa Paşa'yı Amasya'ya gönderdi. Şeyh daveti alınca sufilerin âdeti üzere istihareye yattı. Rüyasında Amasya'dan nur saçan bir meşalenin çıııp Müslümanların hâkim olduğu en uzak sınırlara kadar ulaştığını ve oraları nura boğduğunu, sonra bu nurun âlemi kapladığını ve Rum diyarının nurlara ve 1şıklara gark olduğunu gördü. Bu rüyayı irşat faaliyetlerinin tüm Osmanlı ülkesinde yayılarak genişleyeceğine yordu ve daveti kabul etti. Rüyanın tasavvufi düşünce açısından önemli bir yeri olduğu gerek şeyhlerin gerekse müritlerin rüya yorumu konusu üzerinde önemle durdukları bilinmektedir. Bu rüya ile şeyh müritlerine yeni hedefler gösterip onları motive ederken, artık dini grupların yerel

51 Heyet, Doğuştan Günümüze Büyük Osmanlı Tarihi (İstanbul: Çă̆ Yayınları, 1986), $10 / 253$.

52 Bk. Hans Joachim Kisling, "Halveti Tarikatı II", Bilim Sanat Vakfı Yayın Organı, (Şubat 1994), 30-32. 
282 | A. BUDAK / Geçmişten Günümüze Dini Gruplar Olarak Tarikatların Siyasi Yapılarla İlişkileri bir tarikat olmadığının, İstanbul'a giderek ilk önce payitahta sonra da tüm Osmanlı ülkesinde büyük bir güç olacaklarının haberini de veriyordu. ${ }^{53}$

Şeyh maiyyeti ile Amasya'dan ayrılıp İstanbul'a geldi. O zamanlar Üsküdar iskelesi birkaç hanenin bulunduğu bir yer olup meskûn bir alan değildi. Kafile karşıya geçme hazırlıkları yaparken büyük bir fırtına çıtı ve üç gün üç gece sürdü. Şeyh dervişlerini etrafında toplayıp onlara nasihat ederek şunları söyledi: "Aranızda dünya ehli biri vardır, siz paralarınızı vermez iseniz biz karşıya geçemeyiz." Durum araştırılınca bir şeyhin üzerinden üç akçe para çıktı. Şeyh sinirlenip parayı denize attı ve fırtına dindi. Şeyh bu davranışıyla karşıda bekleyenlere şu mesajı veriyordu; biz dünyalık için payitahta gelmiyoruz, tüm dünyalık isteklerimizi burada bırakıp karşıya geçiyoruz. Şeyh İstanbul'da büyük bir tören ile karşılandı. Şehirdeki herkes onu görmek için akın akın karşılama alanına geldi. Hatta Karamânî'nin yakın dostu ve manevi hamisi Şeyh Vefa dahi karşılamada bulundu. ${ }^{54}$

Eskiden beri bu iki dini grup; Zeynîler ile Halvetîler Osmanlı devlet ricali üzerindeki hâkimiyet konusunda birbirleriyle rekabet içindeydiler. Burada iki dini grubun payitahttaki mücadelelerinin nasıl sonuçlandığını da görmekteyiz. Halvetilerin Pir-i sanisi Yahya Şirvanî’nin halifelerinden Ali Halvetî (ö. 867/1462-1463) kuvvetli cezbe sahibi olup nazarı ile ve kulağına bir şeyler söyleyerek insanları yere düşürür, ölü gibi hareketsiz hale getirirdi. Şeyh İstanbul'a gelince devlet yöneticileri, Divan üyeleri ve halkın ileri gelenleri ona intisap edip hizmetine girdi. Bu iltifatın çoğalması aynı zamanda etrafında büyük bir kalabalığın toplanması Fatih'in dikkatinden kaçmadı. Şeyhi saltanatı için bir tehlike olarak gören sultan kısa sürede İstanbul'u terk etmesini istedi ve onu Anadolu'ya gönderdi. Bursa'da ikamet eden Zeyni şeyhi Taceddin Halife (872/1467-68), Ali Halvetî'nin Anadolu'ya sürülmesinde İstanbul'daki dervişleri aracılığıyla önemli rol üstlenmişti. Fatih'in Halvetîlere olan bu mesafeli duruşu Osmanlı devlet ricalinin tarikata olan ilgisini engellemiş ve İstanbul'da tarikat etkisini yitirmişti. Fakat Cemal Halvetî bu mücadelede Cem'in yanında duran Zeynîlere karşı

53 Hulvi, Lemâzât, 414.

54 Karahan, Yusuf Bin Yakup, Menakıb-ı Şerif İncelemesi, 136. 
Bayezid'i desteklemiş, saltanat çekişmesinde kazanan tarafta yer alarak Halvetîlerin galibiyetini ilan etmişti..$^{55}$

Zeynî Şeyhi Vefa bu hadiseden sonra inzivaya çekilerek sultanlar da dâhil hiç kimsenin görüşme talebini kabul etmemiş, münzevi bir hayat sürmeyi tercih ederek bir nevi İstanbul'daki Halvetî hâkimiyetini kabullenmişti. Bu hadiseden sonra etkinliği azalan tarikat, Şeyh Vefa'nın vefatıyla beraber Osmanlı ülkesindeki hâkimiyetini de yavaş yavaş yitirmiştir. ${ }^{56}$

Şeyh Cemal Halvetî İstanbul'da birkaç yerde geçici olarak ikamet edip irşat faaliyetlerini sürdürdü. Amasya'da kapıağası Mustafa Ağa diye tanınan, İstanbul'a gelip vezir olunca Sadrazam Koca Mustafa Paşa diye adlandırılan şeyhin sadık müridi, Sultan Bayezid'den surlara yakın ve Yedikule'nin üzerinde bulunan harap haldeki Kızlar Manastırı Kilisesi'nin kendine verilmesini istedi. Paşanın isteği kabul edilince buraya, cami, medrese, imaret, hamam ve tekkeden müteşekkil bir külliye inşa ettirip, meşihatına da Şeyh Cemal Halvetî'nin geçmesini sağladı. Şeyh burayı aktif bir şekilde kullanarak pek çok halife yetiştirip Osmanlı ülkesinin değişik yerlerine gönderdi. Böylece Halvetî Tarikatı'nın Cemaliyye kolu da buradan ortaya çıkmış oldu. Tekkenin dervişlerin ve halkın nazarındaki yeri o dereceye ulaştı ki Hızır İstanbul'a gelse ya Ayasofya'da ya da Koca Mustafa Paşa külliyesinde olur denmeye başland1. ${ }^{57}$

Sultan Bayezid ile Cem Sultan arasındaki saltanat mücadelesinde meydana gelen olaylar uzun süre kimsenin aklından çıkmadı. Hatta beslenen kinler zamanı gelince ortaya çıkıp tarafları ciddi derecede etkiledi. Bayezid'den sonra saltanata geçen Yavuz Sultan Selim atalarının mezarını ziyaret etmek için devlet erkânıyla beraber Bursa'ya geldi. Sultanın maiyyetinde bu sirada vezirlik görevinde bulunan Koca Mustafa Paşa da bulunuyordu. Yavuz, Cem Sultan'ın mezarını ziyareti esnasında saltanat mücadelesinde amcasının başına gelenleri hatırladı ve ölümüne neden olduğunu söyleyerek Paşa'nın katline karar verdi. Paşa'nın ölümü bile Yavuz'un öfkesini dindirmemiş olacak ki İstanbul'a dönünce içinde Halvetî hankâhının da bulunduğu Koca Mustafa Paşa külliyesinin yıkılmasını emretti. Bu sırada hankâhın şeyhi Cemal

55 Lamî Çelebi, Nefahat, 704.

56 Öngören, Zeyniyye, 200-201.

57 Karahan, Yusuf Bin Yakup, Menakıb-ı Şerif İncelemesi, 137. 
Halvetî'nin Halifesi ve damadı Sünbül Efendi (936/1529) idi. Sünbül Efendi'nin heybetinden korkan saray görevlileri yıkım işleminden vaz geçip saraya döndüler ve durumu Sultana aktardılar. Zaten hiddetli bir yaratılışa sahip olan Yavuz daha da öfkelenerek bizzat kendi yıkmak için külliyeye gitmeye karar verdi. Olaydan haberdar olan Şeyh dervişlerini etrafına toplayıp siyah imame ve siyah asa ile Yavuz'u karşıladı. Şeyhin bu halini gören Sultan'ın içindeki kin ve nefret sevgi ve muhabbete dönüştü. Şeyh, Sultan emri yerine getirmek gerekir, söyleyin baca, ocak ve tepeleri yıksınlar deyince emir üzerine yıkım yapıldı. Bu durum padişahın hoşuna gitti ve üzerindeki beyaz samur kürkü şeyhe hediye etti. Yavuz saraya dönünce adamlarından biri; "Sultanım bu nasıl bir iştir giderken niyetiniz başka idi şimdi başka diye sordu. Sultan cevaben şeyhin iki yanında aslanlara binmiş iki muhafız bulunduğunu görmediniz mi? Ağızlarını açıp kükremekteydiler. Bu halden çok korktum dedi." Padişah ölünceye kadar da ona hürmet etti. ${ }^{58}$

$\mathrm{Bu}$ anlatım gösteriyor ki Cemal Halvetî'nin ölümünden sonra yerine bıraktığı halifesi Sünbül Efendi de Yavuz gibi bir sultanı etkileyecek kadar güçlü bir karizmaya sahipti. Merkez Efendi ve halefleri gibi güçlü şeyh silsilesi İstanbul ve Osmanlı ülkesinde varlığını devam ettirerek Halvetilerin yüzlerce yıl Osmanlı Devleti'ndeki en etkin dini grup olmasını sağlamıştır.

\section{Sonuç}

Fatih'in vefatından sonra Cem Sultan ile Bayezid'in saltanatı ele geçirmek için giriştiği mücadele Osmanlı tarihindeki en önemli siyasi çekişmelerden birisidir. Bu siyasi çekişmenin muhakkak ki yönetici, asker, ayan ve ulema gibi pek çok tarafları olmuş, her bir grup kendi desteklediği şehzadeyi tahta taşımak için gizli, açık pek çok faaliyet içerisinde bulunmuştur. Osmanlı toplumsal yapısı içerisinde etkili bir yere sahip olan meşayih de bu siyasi mücadeleye aktif olarak katılmış, destekledikleri şehzadeyi sultan yapabilmek için kendi etki sahalarında mücadele içerisinde olmuşlardır.

Bu mücadelede Halvetî Tarikatı Şehzade Bayezid'in yanında yer alarak onu desteklerken Zeynî Tarikatı'nın şeyhleri de Cem Sultan'ın tarafında yer almışlardır. Bu iki dini grup kendi otorite sahalarında tarafı oldukları şehzade lehine propaganda yapıp kamuoyu

58 Hulvi, Lemâzât, 428. 
oluşturmakla kalmamış, antipropaganda tekniklerini de kullanarak diğer şehzade aleyhinde kamuoyu oluşması için gayretlerde bulunmuşlardır.

Dini gruplar doğaları gereği siyasi mücadeleler içerisinde olmamaları beklenen yapılar olarak görülürse de şartlar oluştuğunda, alan müsait olduğunda bu çekişmelerin içinde kendilerini bulmuşlardır. Dünyevi olayları düzenlemek için teşkilatlanan siyasi yapılarla temelde uhrevi kaygılar taşıyan ve bu alanla ilgili çözümler ortaya koymayı amaçlayan dini gruplar, bazen iş birliği bazen de çatışma ortamlarında bulunmuşlardır.

Yaptığımız bu olay incelemesinin sonucunda dini grupların hangi şartlar yerine geldiğinde siyasi yapılarla etkileşim içerisinde olduğu ve onların alanlarına müdahil olabildiği konusunda şu sonuçlara ulaşabiliriz:

Her şeyden önce siyaset unsurlarının böyle bir müdahale ve etkilemeye izin verecek iradede olmaları, bu alanı tartışmaya açık hale getirir. Normalde siyaset kendi alanını doldurma konusunda irade sahibi olarak görünse de faklı sebeplerden oluşan siyasi zafiyetler bu alana başka yapıların müdahalesi sonucunu doğurur. Fatih'in kendi döneminde siyasi iradesi dişında hiçbir yapıya devlet işlerinde müdahale izni vermemesi ve otoritesini sarsacak dini grupları sert bir şekilde siyaset alanının dışına çıkarması buna bir örnektir. Fakat onun vefatıyla ortaya çıkan kaos siyasetin otoritesini sarsmış, dini gruplar da dahil pek çok siyaset dışı yapının olaylara müdahil olması neticesini doğurmuştur.

Dini gruplar, ancak hirslı ve karizmatik bir lidere sahip olması ile siyasi alan gibi çetrefilli ve sonucunun ne getireceği belli olmayan bir alana girebilme cesaretini kendinde bulabilir. Çünkü kitleleri kendi ilgi alanlarının dişında bir konuya dâhil olma konusunda etkileyebilme ve motive edebilme gücü ancak karizmatik liderlerin başarabileceği bir olaydır. Böyle bir lider ateşli söylemleriyle bağlılarını gerçekleştirecekleri faaliyetin meşruluğuna ikna eder ve varılacak hedefe kilitleyebilir. Bu olayda Cemal Halvetî sahip olduğu maddi ve manevî özelliklerle dervişlerini motive edip Şehzadenin başına herhangi bir bela gelmeden saltanatı elde etmesi amacını gerçekleştirmiştir.

Siyasi alanda etkili olan dini grupların iyi bir iletişim ağına sahip oldukları görülmektedir. Farklı mekânlarda meydana gelen olaylardan 
haberdar olma ve ona uygun stratejiler geliştirme kabiliyeti ancak iyi bir haberleşme ağına sahip olmakla mümkün olur. Hangi bölgede kimin lehte ve aleyhte faaliyet içinde olduğu bilgisi sağliklı bir şekilde elde edilmeli ki onun karşı propagandası yapılabilsin ve hedefe ulaşmada maniler ortadan kaldırılsın. Anlaşılıyor ki Amasya'daki Cemal Halvetî Anadolu'daki ve İstanbul'daki haber kaynakları sayesinde kimin ne tarafta ve ne faaliyetler içinde olduğu bilgisine sağlıklı bir şekilde ulaşabiliyordu. Konya'da hangi şeyhlerin Cem'i desteklediğinden ve ne tür faaliyetler içinde olduğundan haberdardı. Aynı şekilde İstanbul'daki Karamanî Mehmet Paşa'nın kavuğunun içinde bir vefk taşıdığından haberdardı ve bu vefki kimin yazdığını dahi biliyordu.

Dini grup örgütsel açıdan da yeterli bir birikime sahip olmalıdır. Faaliyet içinde olunan coğrafyada güçlü bir teşkilat ağının bulunması, bağlıları bir arada tutma, gelişen olaylardan onları bilgilendirme, şeyhe olan bağlılığın güçlendirilmesi, ulaşılmak istenen hedef konusunda motivasyonun artırılması, dış yapıları kendi yanına çekme gibi konularda önemli katkılar sağlar. Halvetî Tarikatının gerek Amasya'da gerekse Amasya dışında yaygın olan tekke ağıyla yukarıda bahsedilen faaliyetleri gerçekleştirerek müntesiplerinde ortak bir ideal kazandırma konusunda başarılı olduğu görülmektedir.

Dini grup, içine gireceği siyasi mücadelenin sonunda kendi grup yapısına kazandıracağı önemli avantajları elde edeceğini görmelidir. Çünkü sonucu belli olmayan bir çatışmada olabilmek ve mücadele edebilmek için grubu güdüleyecek güçlü unsurların bulunması gerekir. $\mathrm{Bu}$ güdüleme genel itibariyle grubun genel çıkarları ile alakalı olur ve kişisel bir çıkarlar üzerine kurulmaz. Her yapı geleceğini teminat altına alarak varlığını ileriki zamanlara taşımak ister. Bu başta nitelikli insan gücü ve niteliği seçebilmek için geniş bir kitleyi gerektirir. Bunun gerçekleştirilmesinin yollarından birisi de grubun kurumsal gücünü artırarak bağlılarının bazı dünyevi isteklerinin karşılanmasıyla olur. Cemal Halvetî içine girdiği siyasi mücadeleyi kazandığında müridi olan Kapıağası Mustafa Ağa'nın şehzadeye yakınlığı nedeniyle sadrazam olacağını çok iyi biliyor olmalıydı. Osmanlı Devlet sisteminde padişahtan sonra gelen sadrazamın kendi ihvanlarından biri olmasının o dini grubun mensuplarına kazandıracağı güven çok aşikâr olmakla beraber rakip grupların psikolojisini tahmin etmek hiç de güç olmasa gerekir. 
Dini gruplar içine girdikleri siyasi mücadelede başka yapılarla karşı karşıya gelip, rekabet içinde olurlar. Bu yapılar muhakkak ki aynı kendileri gibi bir lider ve teşkilat yapısına ve mücadele hırsına sahip olabilirler. Bu durumda o yapıları kendi içerisinde zafiyete düşürmek için farklı stratejiler denemek gerekir. Her şeyden önce ortak menfaatlerin siyasi irade tarafından zarara uğratıldığı konusu işlenerek bazılarıyla birliktelikler sağlanır ve bu birlikteliğe katılmayanlar dişlanır. Bunun yanında bu muhalif dini gruplara karşı başka sınıflardaki dostlar harekete geçirilerek baskı unsurları oluşturulabilir. Cemal Halvetî'nin, Fatih'in vakıf mallarını müsadere ederek tarikatları nasıl zor durumda bıraktığı konusunu gündeme getirip Konya'da oluşan Cem ittifakını nasıl kendi tarafına çektiği bunun açık bir göstergesidir. Bu olaydan sonra Şeyh Vefa dışında Karaman ittifakı Sadrazam Karamanî Mehmet Paşa'ya olan desteğini çekmiş, onu savunmasız bırakmıştır. Yalnız kalan Şeyh Vefa da güçlü ittifakın karşısında yeteri kadar direnememiştir. Aynı zamanda İstanbul'daki Yeniçeri ordusunun içinde bulunan Bayezid taraftarı komutanlarla yapılan işbirliği sonucunda başkent kontrol altında tutularak başka yapıların hareketi engellenmiştir. Girişilen teşebbüsler sonucunda sadrazam manevi (ya da maddi) koruması ortadan kaldırılıp savunmasız hale getirilmiş, yeniçeriler tarafından öldürülmüştür. Bu Osmanlı Devlet sisteminde Padişahtan sonra en güçlü insan olan sadrazama karşı yapılan açık bir isyan ve ihtilaldir.

Dini gruplarda, özellikle de sufi temelli gruplarda rüya önemli bir bilgi ve motivasyon kaynağı olup, onun görülmesi, anlatımı ve yorumlanmasının belli kuralları vardır. Rüya herkese anlatılmaz ve herkesten de yorumlanması beklenmez. Rüya yorumlayanın salih bir kişi olması ve bu konuda hissiyatlarının güçlü olması beklenir. Derviş için rüyasını anlatacağı yegâne kişi şeyhi olup onun yorumları önemli bir bilgi kaynağı niteliğindedir. Şeyh dervişin gördüğü rüyalar istikametinde manevi alanda aldığı mesafeyi ölçebilir ve bu konuda ona telkinlerde bulunur. Bunun yanında şeyh rüyalarıyla müntesiplerine dini grubun gelecekte atacağı adımlar ve karşılaşacağı olaylar konusunda ipuçları verir. Rüya onun manevi âlemle irtibatının en önemli aracıdır. Her ne kadar rüya sübjektif bir tecrübe olsa da şeyhin gördüğü rüyalar cemaati açısından bir değer ifade eder ve onun yorumlanmasının önemli bir anlamı vardır. Cemal Halvetî'nin 
288 | A. BUDAK / Geçmişten Günümüze Dini Gruplar Olarak Tarikatların Siyasi Yapılarla İlişkileri İstanbul'a davet edilmesinden sonra istihareye yatması ve gördügü rüya tarikatına yeni ufuklar açmış, dervişlerine güçlü bir motivasyon kazandırmıştır.

Siyaset kurumu, dini grupların kendi otorite alanına yönlendirici ve etkileyici şekildeki müdahale etmelerine her zaman izin vermemiştir. $\mathrm{Bu}$ harici müdahaleler devletin temel ideolojisiyle çatışan sonuçlar ortaya çıkarmaya başladığında, devlet mekanizması bir bütün olarak sert refleksler göstermiştir. İstanbul' da Ali Halvetî'nin etrafına toplanan insanların sayısı Fatih'in saltanatına zarar verecek noktaya geldiğinde, onun Anadolu'ya sürülmesi bir devlet refleksidir. Aynı şekilde Fatih'in etrafında toplanıp genç sultanı etkileyen ve önemli bir siyasi güç alanı oluşturan Hurufilerin fikirleri ve faaliyetleri devlet yapısını tehdit edici boyuta ulaştığında Veziri Azam Mahmut Paşa ve ulemadan Molla Fahreddin Acemi'nin bunların şeyh ve müritlerini Edirne'de Namazgah meydanında diri diri yaktırması da devletin gerektiğinde sert tedbirler alabileceğinin göstergelerindendir. ${ }^{59}$ Yine yukarıda bahsedilen Yavuz'un Koca Mustafa Paşa' yı idam ettirip, onun yaptırdığı ve Halvetîlerin en önemli kurumsal yapısı olan dergahı ve camiyi yıktırma teşebbüsü de bu konuda siyasi iradenin ne kadar radikal kararlar alabildiğinin ispatıdır. Yine mehdilik ve kutupluk gibi iddialarla ortaya çıan, Osmanlı Devleti'nin siyasi otoritesini sarsan dini grupların ve onların liderlerinin hapis, sürgün ve idam gibi cezalara çarptırılarak nasıl etkisiz hale getirildikleri tarihi vakıalarla ortaya konan gerçeklerdir. ${ }^{60}$

Siyasi yapı, dini grup etkileşimi, iş birliği, çatışma, alanlara müdahale, şiddet gibi çeşitli süreçlerle tarih içerisinde gözlenen bir olgu olup, günümüzün de önemli toplumsal olaylarından birisidir. Yakın zamanda ülkemizde yaşanılan bu bağlamdaki olaylar bilim adamlarını olayların sebepleri ve sonuçlarını araştırmaya itmiş, çeşitli değerlendirmeler yapmalarına neden olmuştur. Biz bu çalışma ile bazı yazarların paralel devlet yapılanmasına benzettikleri Halvetîlerin Şehzade Bayezid, Cem Sultan arasındaki saltanat mücadelesinde nasıl etkin rol aldıklarını şeyh, mürit, ihvan, saltanat, kavramları çerçevesinde değerlendirdik. Bu mücadelenin anlatımını sufi kaynaklardan, onların merkezinde olduğu yaklaşımdan ele alarak, resmi tarih yazımının

59 İrfan Gündüz, Osmanlılarda Devlet Tekke Münasebetleri (Ankara: Seha Neşriyat, 1983), 31-32.

60 Ali Coşkun, Mehdilik Fenomeni (İstanbul: İz Yayıncılık, 2004), 347-445. 
A. BUDAK / The Relationship Between the Sect as Religious Group and Political Structures from Past to Nowadays | 289 dışında siyaset-dini grup ilişkilerini nasıl değerlendirdiklerini anlatmaya çalıştık. Sonuçta dini grup siyaset ilişkisinde bazen sert çatışmaların yaşandığı durumlar ortaya çıksa da her iki tarafın birbirine ihtiyaç duyduğunda liderler ve isimler ne olursa olsun her zaman iş birliği yapabilecekleri, egemenlik alanlarına müdahale edildiğinde toplumu etkileyen şiddetli çatışmaların olacağı anlaşılmaktadır.

\section{Kaynakça}

Abdizade, Hüseyin Hüsameddin. Amasya Tarihi. 5 Cilt. yay. haz. Mesut Aydın - Güler Aydın. Amasya: Amasya Belediyesi Kültür Yayınları, 2007.

Abdurrahman Cami. Nefahattül Üns. çev. Lami Çelebi. yay. yaz. Süleyman Uludă̆ - Mustafa Kara. İstanbul: Marifet Yayınları, 1998.

Akyüz, Niyazi. Dinin Örgütsel İklimi. Ankara: Gündüz Yayıncılık, 2007.

Aşıkpaşazade. Osmanoğullarının Tarihi. çeviri ve günümüz diline aktarım: Kemal Yavuz - M. A. Yekta Saraç. İstanbul: K Yayınları, 2003.

Budak, Abdulhamit. Bir Şehir Bir Tarikat. Amasya ve Halvetilik. Amasya: Amasya Belediyesi Kültür Yayınları, 2016.

Cengil, Muammer. Tasavoufi Yaşantı. Ankara: Türkiye Diyanet Vakfı Yayın Matbaacılık ve Ticaret İşletmesi, 2008.

Coşkun, Ali. Mehdilik Fenomeni. İstanbul: İz Yayıncılık, 2004.

Çakmak, Muharrem. Cemal Halveti, Hayatı, Eserleri, Tasavvufi Düşüncesi ve Cemâliye Kolu. Erzurum: Atatürk Üniversitesi, Doktora Tezi, 2000.

Dini Terimler Sözlüğü. Ankara: Milli Eğitim Bakanlığı Devlet Kitapları Müdürlüğü, 2009.

Doğan, D. Mehmet. Tarih ve Toplum. Ankara: Rehber Yayınları, 1989.

Ficther, Joseph. Sosyoloji Nedir? çev. Nilgün Çelebi. Ankara: Attila Kitabevi, 1996.

Gölpınarlı, Abdülbâki. Yüz Soruda Türkiye'de Mezhepler ve Tarikatlar. İstanbul: Gerçek Yayınevi, 1969.

Günay, Ünver. Din Sosyolojisi. İstanbul: İnsan Yayınları, 2000.

Günay, Ünver - Ecer, A. Vehbi. Tasavvuf, Tarikatlar ve Türkiye. Kayseri: Erciyes Üniversitesi Yayınları, 1999. 
290 | A. BUDAK / Geçmişten Günümüze Dini Gruplar Olarak Tarikatların Siyasi Yapılarla İlişkileri

Gündüz, İrfan. Osmanlllarda Devlet Tekke Münasebetleri. Ankara: Seha Neşriyat, 1983.

Güngör, Erol. İslam Tasavvufunun Meseleleri. İstanbul: Ötüken Yayınları, 2004.

Heyet. Doğuştan Günümüze Büyük Osmanlı Tarihi. 14 Cilt. İstanbul: Çağ Yayınları, 1986.

Hoca Sadettin Efendi. Tacü't-Tevarih. sad. İsmet Parmaksızoğlu. 5 Cilt. İstanbul: Kültür Bakanlığı Yayınları, 1979.

İnalcık, Halil. “II. Mehmet”. İslam Ansiklopedisi. 7/506-535. Ankara: MEB Yayınları, 1997.

İnalcık, Halil. Osmanlı İmparatorluğu Klasik Çă̆ (1300-1600). çev. Ruşen Sezer. İstanbul: Yapı Kredi Yayınları, 2003.

İsmail Paşa. Hediyyetü'l-Ârifin. 6 Cilt. Beyrut: Dâr-ül kütüb-ül ilmiyye, 1992.

Karahan, Emine. Yûsuf Bin Yâkub'un Menâkıb-ı Şerîf ve Tarîkatnâme-i Pîrân ve Meşâyih-i Tarîkat-ı Aliyye-i Halvetiyye Adlı Eserinin Incelenmesi. İstanbul: İstanbul Üniversitesi, Sosyal Bilimler Enstitüsü, Yüksek Lisans Tezi, 2016.

Karataş, Hasan. "The City as a Historical Actor: The Urbanization and Ottomanization of The Halvetîye Sufi Order by the City of Amasya in the Fifteenth and Sixteenth Centuries". USD: University of California, Doktora Tezi, 2011.

Kisling, Hans Joachim. "Halveti Tarikatı II". Bilim Sanat Vakfi Yayın Organi. (Şubat 1994), 30-35.

Köse, Fatih. "İstanbul'daki Halvetî Tekkelerine Dair". Keşkül Dergisi 23 (2012), 124.

Lâmî Çelebi. Nefahat'l-üns Tercüme ve Şerhi. haz. Süleyman Uludağ Mustafa Kara. İstanbul: Marifet Yayınları, 1998.

Mahmud Cemaleddin el-Hulvî. Lemâzât-ı Hulviyye el-Lemezât-ı 'Ulviyye. haz. Mehmet Serhan Tayşi. İstanbul: Semerkand Yayınları, 2013.

Mardin, Şerif. Din ve İdeoloji. İstanbul: İletişim Yayınları, 1992.

Mecdî Efedi. Tercüme-i Şakayık-ı Nu'maniye. İstanbul: Darüt Tıbaatül Amire, 1269.

Ocak, Ahmet Yaşar. Kültür Tarihi Kaynă̆ı Olarak Menakıbnâmeler. İstanbul: Türk Tarih Kurumu Yayınları, 1997.

Ocak, Ahmet Yaşar. Osmanlı Sufiliğine Bakışlar. İstanbul: Timaş, 2011.

Okumuş, Ejder. Toplumsal Değişme ve Din. İstanbul: İnsan Yayınları, 2012. 
A. BUDAK / The Relationship Between the Sect as Religious Group and Political Structures from Past to Nowadays | 291

Öngören, Reşat. Osmanlılarda Tasavouf. İstanbul: İz Yayıncılık, 2003.

Öngören, Reşat. Tarihte Bir Aydın Tarikatı Zeyniler. İstanbul: İnsan Yayınlar, 2003.

Öztuna, Yılmaz. Devletler ve Hanedanlar. 2 Cilt. Ankara: Kültür Bakanlığı Yayınları, 1990.

Subaşı, Necdet. Din Sosyolojisi. İstanbul: Dem Yayınları, 2014.

Şapolyo, Enver Behnan. Mezhepler ve Tarikatlar Tarihi. İstanbul: Milenyum Yayınları, 2013.

Şükürov, Zaur. "Anadoluda Faaliyet Gösteren İlk Halvetî Şeyhlerinden Muhammed Bahauddin Erzincani”. Keşkül Dergisi, 23 (2012), 4647.

Tayşi, Mehmet Serhan. "Ömer Halvetî". Türkiye Diyanet Vakfi İslam Ansiklopedisi. 34/65. Ankara: TDV Yayınları, 2007.

Uludağ, Süleyman. "İhvan". Türkiye Diyanet Vakfı İslam Ansiklopedisi. 21/580. Ankara: TDV Yayınları, 2000.

Ülgener, Sabri. Zihniyet ve Din. İstanbul: Derin Yayınları, 2006.

Uzunçarşıll, İsmail Hakkı. Osmanlı Tarihi. 6 Cilt. Ankara: Türk Tarih Kurumu Yayınları, 1988.

Weber, Max. Sosyoloji Yazıları. çev. Taha Parla. İstanbul: Hürriyet Vakfı Yayınları, 1986.

Weber, Max. Din Sosyolojisi. çev. Latif Boyacı. İstanbul: Yarın Yayınları, 2012.

Yetik, Erhan. Tarikatlar ve Dini Hayat. Samsun: Kardeşler Ofset, 1996. 